\title{
The effects of ruminally degraded protein on rumen fermentation and ammonia losses from manure in dairy cows
}

\author{
M. Agle, ${ }^{*}$ A. N. Hristov, ${ }^{* 1,2}$ S. Zaman, ${ }^{*}$ C. Schneider, ${ }^{*}$ P. Ndegwa, $†$ and V. K. Vaddella† \\ *Department of Animal and Veterinary Science, University of Idaho, Moscow 83844 \\ †Department of Biological Systems Engineering, Washington State University, Pullman 99164
}

\begin{abstract}
This experiment investigated the effect of dietary crude protein $(\mathrm{CP})$ and ruminally degraded protein (RDP) levels on rumen fermentation, digestibility, ammonia emission from manure, and performance of lactating dairy cows. The experiment was a replicated $3 \times 3$ Latin square design with 6 cows. Three diets varying in $\mathrm{CP}$ concentration were tested (CP, \% of dry matter): 15.4 (high CP, control), 13.4 (medium CP), and $12.9 \%$ (low CP). These diets provided metabolizable protein balances of $323,-44$, and $40 \mathrm{~g} / \mathrm{d}$ and RDP balances of $162,-326$, and $-636 \mathrm{~g} / \mathrm{d}$ (high, medium, and low, respectively). Both the medium and low CP diets decreased ruminal $\mathrm{pH}$ compared with high $\mathrm{CP}$, most likely because of the higher nonfiber carbohydrate concentration in the former diets. Ruminal ammonia pool size (rumen ammonia $\mathrm{N}$ was labeled with ${ }^{15} \mathrm{~N}$ ) and the concentration of total free amino acids were greater for the high $\mathrm{CP}$ diet than for the RDP-deficient diets. Apparent total-tract nutrient digestibilities were not affected by treatment. Both the medium and low CP diets resulted in lower absolute and relative excretion of urinary $\mathrm{N}$ compared with the high $\mathrm{CP}$ diet, as a proportion of $\mathrm{N}$ intake. Excretion of fecal $\mathrm{N}$ and milk yield and composition were not affected by diet. Milk $\mathrm{N}$ efficiency (milk $\mathrm{N} \div \mathrm{N}$ intake) and the cumulative secretion of ammonia- ${ }^{15} \mathrm{~N}$ in milk protein were greater for the RDP-deficient diets, and milk urea $\mathrm{N}$ concentration was greater for the high $\mathrm{CP}$ diet. Both medium and low $\mathrm{CP}$ diets decreased the irreversible loss of ruminal ammonia $\mathrm{N}$ compared with the high $\mathrm{CP}$ diet. The rate and cumulative ammonia emissions from manure were lower for the medium and low $\mathrm{CP}$ diets compared with the high CP diet. Overall, this study demonstrated that dairy diets with reduced $\mathrm{CP}$ and $\mathrm{RDP}$ concentrations will produce manure with lower ammonia-emitting po-
\end{abstract}

Received July 21, 2009.

Accepted December 11, 2009

${ }^{1}$ Corresponding author: anh13@psu.edu

${ }^{2}$ Current address: Department of Dairy and Animal Science, The Pennsylvania State University, University Park 16802. tential without affecting cow performance, if metabolizable protein requirements are met.

Key words: ruminally degraded protein, urinary nitrogen, ammonia emission, dairy cow

\section{INTRODUCTION}

The interaction of dietary protein with energy and its effect on ruminal fermentation and dairy cow performance are complex processes. Amino acids can be used for gluconeogenesis (Bergman and Heitmann, 1978 ) in the tissues, or serve as an energy source for ruminal microorganisms (Russell and Wallace, 1997). In addition, dietary peptides and amino acids have a specific stimulating effect on microbial protein synthesis in the rumen (Walker et al., 2005). When protein is overfed, however, its efficiency of utilization for production sharply decreases and a significant amount is lost to the environment as fecal, urinary, and gaseous N. Overfeeding of protein to dairy cows can also have an energetic toll (Milano et al., 2000) and potentially a negative effect on reproductive performance (Ferguson and Sklan, 2005).

The consequence of these complex effects of dietary protein on animal performance has been a trend for protein overfeeding in intensive dairy production systems (Jonker et al., 2002; Hristov et al., 2006). Deficiencies of the current feeding systems for dairy cows have aggravated the problem (Schwab et al., 2005; Huhtanen and Hristov, 2009). As a result, whole-farm N surplus (imported $\mathrm{N}$ less $\mathrm{N}$ exported off the farm with milk and manure) can be significant (Hristov et al., 2006), exacerbating the environmental impact of livestock operations. Volatile $\mathrm{N}$ loss from manure, primarily ammonia, along with ground and surface water pollution, is perhaps one of the most environmentally important public concerns related to animal agriculture today. Ammonia emitted from animal manure is a major air and water pollutant contributing to eutrophication, aerosol formation, acid rain, and impaired visibility (USEPA, 2004). The importance of mitigating ammonia emissions from livestock operations in the United States relates primarily to the contribution of ammonia to formation of 
fine particles with aerodynamic diameter less than 2.5 $\mu \mathrm{m}\left(\mathrm{PM}_{2.5}\right)$, which have detrimental effects on human health (Oberdorster, 2000; Miller et al., 2007). Factors affecting ammonia emissions from animal manure are complex and have been thoroughly reviewed (Ndegwa et al., 2008). Dietary protein concentration is perhaps the most important on-farm variable that can be controlled relatively easily (and practically), and it can have a significant and immediate, measurable effect on ammonia emissions. As the relationship between dietary CP level and urinary urea excretion is linear (Olmos Colmenero and Broderick, 2006) and urea is the main contributor to ammonia emission from livestock facilities (Bussink and Oenema, 1998; Thomsen, 2000), reducing ration $\mathrm{CP}$ would effectively reduce volatile $\mathrm{N}$ losses from manure (Frank et al., 2002). A similar effect would be expected from reducing dietary RDP concentration (Van Duinkerken et al., 2005). With high-producing cows, lowering dietary CP may, in certain situations, result in decreased milk yield (Broderick, 2003), which would be unacceptable to most producers and nutritionists in the field. However, these performance effects stem, in most cases, from the complex interactions of protein with DM and energy intake (see discussion by Huhtanen and Hristov, 2009). In addition, the current dairy NRC (2001) likely overestimates the RDP needs of the cow because of inaccurate feed RDP determination and urea $\mathrm{N}$ recycling to the rumen, unaccounted for by the model (Huhtanen and Hristov, 2009). Therefore, a reduction of dietary CP by lowering RDP should not cause loss of production if metabolizable protein requirements are met.

The primary objective of this study was to investigate the effect of dietary protein, specifically RDP, on ammonia emissions from dairy manure, and to demonstrate that emissions can be reduced by feeding RDP-deficient diets.

\section{MATERIALS AND METHODS}

Animals involved in this study were cared for according to the guidelines of the University of Idaho Animal Care and Use Committee. The committee reviewed and approved the experiment and all procedures carried out in the study.

\section{Experimental Design and Treatments}

Six multiparous Holstein cows $(646 \pm 26.2 \mathrm{~kg}$ BW; $179 \pm 35.8$ DIM at the beginning of the trial) fitted with 10-cm ruminal cannulas (Bar Diamond, Parma, ID) were used in this experiment. Cows were randomly assigned to experimental treatments in a replicated 3 $\times 3$ Latin square design balanced for residual effects
(Cochran and Cox, 1992). Treatments were as follows: control or high CP (HCP) diet $(15.4 \%$ CP, DM basis), medium CP (MCP) diet, $13.4 \% \mathrm{CP}$, and low CP (LCP) diet, $12.9 \%$ CP (Table 1). These diets provided (NRC, 2001) MP balances of $323,-44$, and $40 \mathrm{~g} / \mathrm{d}$ and RDP balances of $162,-326$, and $-636 \mathrm{~g} / \mathrm{d}$ (for $\mathrm{HCP}, \mathrm{MCP}$, and LCP, respectively). The diets were formulated (NRC, 2001) to meet or exceed the energy requirements (at $25 \mathrm{~kg} / \mathrm{d}$ of DMI) of a Holstein cow yielding $35 \mathrm{~kg}$ of milk/d with $3.70 \%$ milk fat and $3.20 \%$ true protein. The original diets were formulated to contain 17.6 (average CP content of diets commonly fed on commercial dairies in Idaho; Hristov et al., 2006), 15.2, and $14.4 \%$ CP (respectively) and to meet the MP requirement of the cows, but exceed (HCP), meet (MCP), or be deficient (LCP) in RDP. Because of changes in forage quality during the trial, however, the actual CP content of the diets was lower and both MCP and LCP diets were RDP-deficient. Cows were fed at 0700 and $1800 \mathrm{~h}$ (50\% of the daily feed allowance at each feeding) and milked at 0600 and $1600 \mathrm{~h}$. Each experimental period consisted of $14 \mathrm{~d}$ for adaptation to treatment and $7 \mathrm{~d}$ for sampling. Feeding was ad libitum to about $5 \%$ orts during the 14 -d adaptation period and limit feeding (90\% of ad libitum calculated from the previous $2 \mathrm{wk}$ ) during the 7 -d sampling period. The cows were housed in box stalls during the adaptation periods and then moved to tie stalls for the duration of the sampling period. We did not observe any signs of stress (DMI remained similar) caused by relocation of the cows. All cows were injected with recombinant bST (500 mg of Posilac, Monsanto, St. Louis, MO) on d 8 of each experimental period. Cows had free access to fresh water during the trial.

\section{Sampling and Measurements}

Samples of individual forage, TMR, and refusals were collected daily, and concentrate feeds were sampled weekly during the entire experiment. Samples were composited per diet and period and analyzed for DM $\left(65^{\circ} \mathrm{C}\right.$ in a forced-air oven, dried to a constant weight) and ash (AOAC, 2000), N (by dry combustion; Foley et al., 2006), NDF (Van Soest et al., 1991), and starch (starch assay kit, Megazyme International Ireland Ltd., Wicklow, Ireland; McCleary et al., 1994). A heat-stable $\alpha$-amylase was used in the NDF analysis. Sodium sulfite was not used in the analysis and NDF was expressed inclusive of residual ash. Composite TMR samples were also analyzed for acid-insoluble ash (AIA; Van Keulen and Young, 1977) as intrinsic digestibility marker.

Ruminal ammonia $\mathrm{N}$ was labeled through a pulse-dose of $2 \mathrm{~g} /$ cow of 99 atom percent excess (APE) ${ }^{15} \mathrm{NH}_{4} \mathrm{Cl}$ (Cambridge Isotope Laboratories Inc., Andover, MA) 
Table 1. Ingredient (\% of ration DM) and chemical composition of the diets fed in the trial

\begin{tabular}{|c|c|c|c|}
\hline \multirow[b]{2}{*}{ Item } & \multicolumn{3}{|c|}{ Diet } \\
\hline & High CP & Medium CP & Low CP \\
\hline \multicolumn{4}{|l|}{ Ingredient } \\
\hline Alfalfa hav ${ }^{1}$ & 18.4 & 9.0 & 7.8 \\
\hline Alfalfa haylage ${ }^{2}$ & 13.3 & 11.4 & 7.4 \\
\hline Grass hay ${ }^{3}$ & - & - & 4.9 \\
\hline Corn silage ${ }^{4}$ & 29.8 & 39.1 & 41.1 \\
\hline Corn grain, ground & 23.4 & 26.5 & 25.4 \\
\hline $\operatorname{SSBM}^{5}(44 \% \mathrm{CP})$ & 3.0 & - & - \\
\hline SoyBest ${ }^{6}$ & 4.8 & 6.2 & 11.0 \\
\hline Canola meal, mechanically extracted & 4.9 & 5.3 & - \\
\hline Mineral, vitamin, fat premix ${ }^{7}$ & 2.4 & 2.5 & 2.5 \\
\hline \multicolumn{4}{|l|}{ Composition, ${ }^{8} \%$ of DM } \\
\hline $\mathrm{CP}$ & 15.4 & 13.4 & 12.9 \\
\hline $\mathrm{RDP}$ & 10.3 & 8.4 & 7.1 \\
\hline RUP & 5.2 & 5.0 & 5.8 \\
\hline NDF & 31.3 & 30.6 & 31.6 \\
\hline $\mathrm{NE}_{\mathrm{L}}, \mathrm{Mcal} / \mathrm{kg}$ & 1.51 & 1.53 & 1.53 \\
\hline $\mathrm{NFC}$ & 44.8 & 47.9 & 47.6 \\
\hline $\mathrm{Ca}$ & 0.94 & 0.80 & 0.73 \\
\hline $\mathrm{P}$ & 0.36 & 0.34 & 0.31 \\
\hline Met, $\%$ of MP & 1.86 & 1.84 & 1.72 \\
\hline Lys, $\%$ of MP & 6.66 & 6.48 & 6.17 \\
\hline \multicolumn{4}{|l|}{$\mathrm{MP}$ balance, $\mathrm{g} / \mathrm{d}$} \\
\hline Required & 2,211 & 2,235 & 2,202 \\
\hline Supplied & 2,534 & 2,191 & 2,242 \\
\hline Balance & 323 & -44 & 40 \\
\hline $\mathrm{MP}$ allowable milk, $\mathrm{kg} / \mathrm{d}$ & 38 & 31 & 31 \\
\hline
\end{tabular}

${ }^{1}$ Alfalfa hay contained (\% of DM): $42 \% \mathrm{NDF}$ and $19 \% \mathrm{CP}$.

${ }^{2}$ Alfalfa haylage was $35 \% \mathrm{DM}$ and contained (\% of DM): $48 \% \mathrm{NDF}$ and $15 \% \mathrm{CP}$.

${ }^{3}$ Grass hay contained (\% of DM): $64 \%$ NDF and $6.3 \%$ CP.

${ }^{4}$ Corn silage was $34 \% \mathrm{DM}$ and contained (\% of DM): $40 \% \mathrm{NDF}$ and $6 \% \mathrm{CP}$.

${ }^{5}$ Soybean meal, solvent extracted.

${ }^{6}$ SoyBest is a source of rumen bypass protein (Grain States Soya, West Point, NE) and contains $49 \% \mathrm{CP}$ and $4.5 \%$ soluble protein (DM basis).

${ }^{7}$ Land O'Lakes (St. Paul, MN). The premix contained (\%, as-is basis): fat nugget, 42; calcium carbonate, 17.2; sodium sesquicarbonate, 7.8; wheat middlings, 7.5; corn grain, ground, 7.1; salt, 6.3; MetaSmart (Adisseo USA Inc., Alpharetta, GA), 5.1; magnesium oxide, 4.5; trace mineral/vitamin premix, 2.5. Composition (DM basis): fat, 18.9\%; Ca, 7.4\%; Na, 5.1\%; P, 0.23\%; Mg, 2.77\%, S, 0.21\%; Cu, $488 \mathrm{mg} / \mathrm{kg} ; \mathrm{Zn}, 2,454 \mathrm{mg} / \mathrm{kg} ; \mathrm{Mn}, 77.1$ $\mathrm{mg} / \mathrm{kg}$; Fe, $464 \mathrm{mg} / \mathrm{kg}$; Se, $8.15 \mathrm{mg} / \mathrm{kg} ;$ Co, $2.3 \mathrm{mg} / \mathrm{kg} ; \mathrm{I}, 21.0 \mathrm{mg} / \mathrm{kg}$; vitamin A, 148,016 IU/kg; vitamin D, 23,122 IU/kg; and vitamin E, $960 \mathrm{IU} / \mathrm{kg}$.

${ }^{8}$ Estimated based on NRC (2001), except CP and NDF, which were analyzed.

dissolved in $5 \mathrm{~L}$ of McDougall's buffer (McDougall, 1948). Rumens of the cows were emptied in large carts before the a.m. feeding on $\mathrm{d} 15$ of each period and weighed. Then, a background ruminal sample was collected, ${ }^{15} \mathrm{NH}_{4} \mathrm{Cl}$ and Cr-EDTA $(1 \mathrm{~L} / \mathrm{cow}$, equivalent of $2.5 \mathrm{~g}$ of $\mathrm{Cr} /$ cow; Udén et al., 1980) were added and thoroughly mixed with the ruminal contents, a $0-\mathrm{h}$ sample was collected, and the ruminal contents were returned to the rumen. Chromium-EDTA was used as a ruminal liquid passage rate marker.

Whole ruminal contents samples were collected at 1 , $2,4,6,8,10,14,18$, and $24 \mathrm{~h}$ following the a.m. feeding on d 17 of each experimental period. Ruminal samples were collected from 4 locations in the reticulo-rumen (ventral sac, reticulum, and 2 from the feed mat in the dorsal rumen; approximately $250 \mathrm{~g}$ each), composited, and analyzed for DM and ${ }^{15} \mathrm{~N}$ enrichment of the ammonia $\mathrm{N}$ and bacterial $\mathrm{N}$. Aliquots of the rumen samples were filtered through 2 layers of cheesecloth and centrifuged $\left(20,000 \times g\right.$ for $15 \mathrm{~min}$ at $\left.4^{\circ} \mathrm{C}\right)$; the supernatant fluid was analyzed for Cr (Soon, 1998; Iris ICP atomic emission spectrophotometer, Thermo Jarrell Ash Corp., Franklin, MA). The fractional outflow rate of the ruminal fluid was calculated as Ln-transformed Cr concentrations plotted against time. Aliquots of the rumen cheesecloth filtrates were immediately analyzed for $\mathrm{pH}$ and processed for analyses of ammonia and total free amino acids (TFAA; Hristov et al., 1999), VFA (Foley et al., 2006), and polysaccharide-degrading [carboxymethylcellulase (CMCase), amylase, and xylanase] activities (Hristov et al., 1998). Individual ruminal fluid samples were analyzed for ammonia and $\mathrm{pH}$; the 
remaining analyses were performed on composite (volume base, per cow and period) samples.

Methane production in the rumen was measured utilizing the sulfur hexafluoride $\left(\mathbf{S F}_{6}\right)$ tracer technique (Johnson et al., 1994). The $\mathrm{SF}_{6}$ permeation tubes were prepared by K. Johnson (Washington State University, Pullman, WA; Johnson et al., 2007). The tubes were placed in the reticulum of the cows on $\mathrm{d} 1$ of the experiment and remained there throughout the duration of the study. Gas samples for methane analysis were collected directly from the rumen through modified rumen cannula lids (Hristov et al., 2009a). Sampling started $2 \mathrm{~h}$ after the morning feeding and 5 gas samples were collected every hour; that is, at $2,3,4,5$, and $6 \mathrm{~h}$ after the morning feeding. Gas samples were analyzed for methane and $\mathrm{SF}_{6}$ using gas-liquid chromatography (Hristov et al., 2009a). Production of methane was calculated as the release rate of $\mathrm{SF}_{6}$ times the ratio of the concentration of methane to $\mathrm{SF}_{6}$ in the ruminal headspace (Johnson et al., 1994).

Fecal samples (400 g per sampling) were collected from the rectum or the ground, when fresh, during d 16 and 17 of each sampling period at 0900,1500 , and 2100 $\mathrm{h}$ (d 16), and at 0300, 0600, 1200, 1800 (d 17), and 0000 h. Samples were dried at $65^{\circ} \mathrm{C}$ in a forced-air oven to constant weight, composited per animal and period, and ground through a $1-\mathrm{mm}$ sieve. Samples were analyzed for ash, N, NDF, starch, and AIA. Apparent total-tract digestibility was estimated using AIA as an intrinsic digestibility marker (Foley et al., 2006). At each sampling, a second fecal sample (approximately $300 \mathrm{~g}$ ) was collected, composited (per cow and period), and frozen immediately $\left(-80^{\circ} \mathrm{C}\right)$ for analysis of ammonia-emitting potential of manure.

Total urine was collected during the last $4 \mathrm{~d}$ of each period. Urinary catheters (22 French, $75 \mathrm{~mL}$, C. R. Bard Inc., Covington, GA) were positioned in the cows $24 \mathrm{~h}$ before initiation of urine collection. Urine samples were acidified during collection to a $\mathrm{pH}<3.0$ by addition of $2 \mathrm{M} \mathrm{H}_{2} \mathrm{SO}_{4}$. The acid solution was added in the urine containers at the beginning of the collection period. Aliquots were diluted 1:10 with distilled water, stored frozen at $-20^{\circ} \mathrm{C}$, and later analyzed for $\mathrm{N}$, allantoin (Chen, 1989), and uric acid (Uric acid kit 1051, Stanbio Laboratory, San Antonio, TX). Urinary excretion of allantoin and uric acid was used to estimate duodenal microbial protein flow (Broderick and Merchen, 1992). At the beginning of each urine collection period, an unacidified urine sample (approximately $2 \mathrm{~L}$ ) was collected from each cow and frozen immediately $\left(-80^{\circ} \mathrm{C}\right)$ for analysis of ammonia-emitting potential of manure. During period 3 of the experiment, one of the cows on HCP developed a urinary infection, and urinary data for this cow were not used in the analysis, except for the initial unacidified urine sample that was used for ammonia emission measurements.

The ammonia-emitting potential of manure resulting from the experimental diets was measured in laboratory-scale postcollection simulated storage with appropriate instrumentation. This system, which consisted of a manure-storage, an acid bottle to trap the emitted ammonia, a flow meter to regulate sweep-air, and a vacuum pump to pull air through the system was adopted from previous similar studies (Shi et al., 2001; Misselbrook et al., 2005; Ndegwa et al., 2009). Air to facilitate and carry emitted ammonia from the manure storage headspace was drawn using the vacuum pump at a flow rate of $1 \mathrm{~L} / \mathrm{min}$. The air carrying emitted ammonia was bubbled through a previously calibrated 0.2 $M$ sulfuric acid bottle to trap ammonia. Acid samples for analysis of the trapped ammonia were collected every day during the first week and every other day during the second week. Samples were immediately analyzed for ammonia concentration using standard methods (APHA, 1998). The manures for these analyses were reconstituted from the respective samples of feces and urine that had previously been collected separately and frozen. Before reconstitution, the frozen feces and urine samples were allowed to thaw at room temperature. The feces and urine were mixed in the ratio of $1.7: 1$ $(1,700 \mathrm{~g}$ of feces and 1,000 $\mathrm{g}$ of urine) on a weight basis to reconstitute the manure. The feces to urine excretion ratio in lactating dairy cows had been established in previous studies (Vander Pol et al., 2007, 2008).

Milk yield data were collected daily and milk samples (p.m. and a.m. milkings) for composition analyses (fat, true protein, and MUN; Washington DHIA, Burlington, WA) were collected on $3 \mathrm{~d}$ during the last $2 \mathrm{wk}$ of each experimental period. Milk yield data for the $7 \mathrm{~d}$ before the ${ }^{15} \mathrm{~N}$ dose were used in the statistical analysis. Following the ${ }^{15} \mathrm{~N}$ dose, cows were milked at 0 (background) , 5, 10, 15, 20, 25, 30, 35, 40, 45, 50, 55, $60,65,70,75,80,85,90,95,107,119,131$, and 143 $\mathrm{h}$ in the tie stalls, using portable milking equipment. At each milking, milk weights were recorded and milk samples were collected for analysis of ${ }^{15} \mathrm{~N}$-enrichment of milk protein (Hristov and Ropp, 2003).

On d 20 of each experimental period, blood samples were collected from the tail vein or artery before $(0 \mathrm{~h})$ and $6 \mathrm{~h}$ after the a.m. feeding. Plasma was collected after centrifugation at $1,500 \times g$ for $40 \mathrm{~min}$, frozen at $-40^{\circ} \mathrm{C}$, and later analyzed for urea $\mathrm{N}$ (Urea Nitrogen kit, cat. no. 640-8; Sigma Diagnostics, St. Louis, MO).

Body weight of the cows was recorded at the beginning and at the end of the experiment and at the beginning of periods 2 and 3 . 


\section{Calculations}

Pool size of ruminal ammonia N, areas under the ${ }^{15} \mathrm{~N}$ enrichment (APE) curves (AUC) for ruminal ammonia, bacterial $(\mathbf{B N})$, and milk protein $\mathrm{N}(\mathbf{M P N})$, and the proportions of MPN originating from ruminal BN and ammonia $\mathrm{N}$ and the proportion of $\mathrm{BN}$ originating from ruminal ammonia $\mathrm{N}$ were calculated as described elsewhere (Hristov et al., 2005). The average adjusted $\mathrm{r}^{2}$ for the ruminal ammonia and BN models were 0.998 \pm 0.0004 and $0.94 \pm 0.006$, respectively. The average proportion of the variance explained by the MPN model (regression sum of squares $\div$ uncorrected total sum of squares) was $0.99 \pm 0.002$. Irreversible loss and the efficiency of utilization of ruminal ammonia $\mathrm{N}$ for microbial protein synthesis were calculated as described in Hristov et al. (2005).

The cumulative amount of ${ }^{15} \mathrm{~N}$ secreted in milk protein (as percentage of ${ }^{15} \mathrm{~N}$ dosed) was fitted to a single rectangular 2-parameter hyperbola model and the estimated maximum secretion and overall secretion lines were compared among treatments using dummy variable regression technique (PROC NLIN, SAS Institute, Cary, NC; Hristov et al., 2005). The average proportion of the variance explained by the model (regression sum of squares $\div$ uncorrected total sum of squares) was 0.97 \pm 0.001 .

Urinary purine derivative (PD) excretion was used to estimate duodenal microbial N (MN) flow assuming that (1) absorption of microbial purine bases $(\mathrm{mmol} / \mathrm{d})$ $=\left(\mathrm{PD}-0.385 \times \mathrm{BW}^{0.75}\right) \div 0.85$, where $\mathrm{PD}$ is the urinary PD excretion (allantoin and uric acid; $\mathrm{mmol} / \mathrm{d}$ ), $0.385 \mathrm{mmol} / \mathrm{kg}$ of $\mathrm{BW}^{0.75}$ is a correction for endogenous $\mathrm{PD}$, and 0.85 is a recovery coefficient (Verbic et al., 1990) and (2) Duodenal MN flow $(\mathrm{g} \mathrm{N} / \mathrm{d})=($ absorbed microbial purine bases $\times 70) \div(0.83 \times 0.134 \times 1,000)$, where 70 is the $\mathrm{N}$ content of purines $(\mathrm{mg}$ of $\mathrm{N} / \mathrm{mmol}$; Chen et al., 1992) and 0.134 is the ratio of purine $\mathrm{N}$ to total $\mathrm{N}$ in rumen microorganisms assumed based on the data of Valadares et al. (1999) and a digestibility coefficient of 0.83 for microbial purines (Chen et al., 1992).

\section{Statistical Analysis}

Data were analyzed using the PROC MIXED procedure of SAS (2003 version; SAS Institute Inc., Cary, $\mathrm{NC})$. Intake, digestibility, rumen fermentation data (except pH, ammonia concentration, methane production, and ${ }^{15} \mathrm{~N}$ enrichment of ammonia $\mathrm{N}, \mathrm{BN}$, and MPN), urinary excretions, milk yield and composition, some of the ${ }^{15} \mathrm{~N}$-enrichment data, and end-point (d 15) cumulative ammonia emission from manure data were analyzed by ANOVA Latin square. The milk composi- tion samples collected during each experimental period were averaged per cow, and the average values were used in the statistical analysis and to calculate FCM, milk $\mathrm{NE}_{\mathrm{L}}$ yield, and milk fat and protein yields. The model used was

$$
\mathrm{Y}_{\mathrm{ijkl}}=\mu+\mathrm{S}_{\mathrm{i}}+\mathrm{C}(\mathrm{S})_{\mathrm{ij}}+\mathrm{P}_{\mathrm{k}}+\tau_{\mathrm{l}}+\mathrm{e}_{\mathrm{ijkl}},
$$

where $Y_{i j k l}$ is the dependent variable, $\mu$ is the overall mean, $\mathrm{S}_{\mathrm{i}}$ is the square, $\mathrm{C}(\mathrm{S})_{\mathrm{ij}}$ is the cow within square, $\mathrm{P}_{\mathrm{k}}$ is the kth period, $\tau_{1}$ is the lth treatment, with the error term $e_{i j k l}$ assumed to be normally distributed with mean $=0$ and constant variance. Square and cow within square were random effects, whereas all else were fixed.

Ruminal $\mathrm{pH}$, ammonia concentration, methane production, and ${ }^{15} \mathrm{~N}$ enrichment of ammonia $\mathrm{N}, \mathrm{BN}$, and MPN data were analyzed as Latin square repeated measures assuming an autoregressive [1] covariance structure. The model used was:

$$
\begin{aligned}
\mathrm{Y}_{\mathrm{ijk} k \mathrm{~m}}=\mu+ & \mathrm{S}_{\mathrm{i}}+\mathrm{C}(\mathrm{S})_{\mathrm{ij}}+\mathrm{P}_{\mathrm{k}}+\tau_{1}+\mathrm{D}_{\mathrm{m}} \\
& +\tau \mathrm{D}_{\mathrm{lm}}+\mathrm{e}_{\mathrm{ijklm}},
\end{aligned}
$$

where $Y_{\mathrm{ijklm}}$ is the dependent variable, $\mu$ is the overall mean, $\mathrm{S}_{\mathrm{i}}$ is the square, $\mathrm{C}(\mathrm{S})_{\mathrm{ij}}$ is the cow within square, $\mathrm{P}_{\mathrm{k}}$ is the kth period, $\tau_{1}$ is the lth treatment, $\mathrm{D}_{\mathrm{m}}$ is the time effect, $\tau D_{l m}$ is the treatment $\times$ time interaction with the error term $e_{i j k l m}$ assumed to be normally distributed with mean $=0$ and constant variance. Square and cow within square were random effects, whereas all else were fixed.

Cumulative ammonia emission from manure data fitted well a linear model $\left(\mathrm{r}^{2}=0.99\right)$ and were analyzed as linear regression (cumulative ammonia emission, $\mathrm{mg}$ of $\mathrm{N}=$ intercept + slope $\times$ incubation day; PROC GLM, SAS Institute).

Statistical differences were declared at $P \leq 0.05$. Differences between treatments at $P \leq 0.10$ were considered as a trend toward significance.

\section{RESULTS}

At the actual DMI observed in this experiment, the HCP diet supplied about 15\% more MP than required for the level of production of the cows and exceeded RDP requirements by about $7 \%$ as specified by NRC (2001; Table 1). The MCP and LCP diets approximately met the requirements of the cows for MP (about $2 \%$ below and $2 \%$ above the requirements for MCP and LCP, respectively), but were 14 and $27 \%$ deficient (respectively) in RDP. Because corn silage replaced alfalfa forage to decrease $\mathrm{CP}$ and RDP concentrations, diets 
MCP and LCP also had slightly greater (about 6 to $7 \%$ ) concentrations of NFC.

Both MCP and LCP decreased ruminal pH compared with the control (Table 2), an effect that was most likely related to the higher NFC concentration in the former diets (Table 1). There was no treatment $x$ time of sampling interaction for rumen $\mathrm{pH}$. Both $\mathrm{MCP}$ and LCP diets reduced (by 25 to $29 \%$ ) the concentration of ammonia in ruminal fluid. Treatment $\times$ time of sampling interaction was significant. However, except for 6 and $8 \mathrm{~h}$ postfeeding, ammonia concentration was consistently higher $(P<0.05)$ for the control diet (HCP) compared with the RDP-deficient diets (Figure 1). Ruminal ammonia $N$ pool size (immediately before feeding, i.e., at time $0 \mathrm{~h})$ tended to be greater $(P=$ 0.067) for MCP compared with HCP. Estimated based on ${ }^{15} \mathrm{~N}$ kinetics data (covering the entire 24 -h sampling cycle), ruminal ammonia $\mathrm{N}$ pool size was larger for HCP compared with MCP and LCP. Rumen TFAA concentration was greater for HCP compared with the RDP-deficient diets. There was no difference in ruminal VFA concentrations or acetate:propionate ratio among treatments, except that isobutyrate concentration was lower for LCP compared with HCP and MCP. Treatment did not affect polysaccharide-degrading activities of ruminal contents. Ruminal methane production (or concentration, data not shown) was similar among diets. Fractional outflow rate of ruminal fluid was also similar among treatments. Diet did not affect urinary excretion of allantoin, uric acid (trend at $P=0.08$ ), and consequently total PD excretion. Estimated ruminal outflow of MN was also not different among treatments.

Milk yield, 4\% FCM yield, milk $\mathrm{NE}_{\mathrm{L}}$ yield, and milk fat, true protein, and lactose concentrations and yields were not different among diets (Table 3 ). Feed efficiency (milk yield $\div$ DMI) was numerically greater $(P=$ 0.13 ) for the RDP-deficient diets compared with HCP. Diet did not affect true milk protein $\mathrm{N}$ yield, but as proportion of $\mathrm{N}$ intake (i.e., milk $\mathrm{N}$ efficiency, MNE) it was greater for MCP and LCP compared with HCP. Both MCP and LCP decreased MUN concentration compared with the control diet. The LCP diet reduced plasma urea $\mathrm{N}$ concentration compared with the control and MCP. Cow BW tended to be greater $(P=$ $0.08)$ for LCP compared with the other diets. All cows gained weight during the trial, but the least $(P=0.08)$ BW gain was observed for the LCP diet (on average $6 \mathrm{~kg}$, compared with 14 to $16 \mathrm{~kg}$ for $\mathrm{MCP}$ and $\mathrm{HCP}$, respectively). Intake of DM and OM did not differ, but intakes of N and NDF were lower or tended to be lower $(P=0.09)$ with MCP and LCP compared with the HCP diet. Starch intake was highest for HCP followed by LCP and MCP. Total-tract apparent digestibility of DM tended to be greater $(P=0.06)$ for HCP and LCP compared with MCP. A similar trend $(P=0.08)$ was observed for starch digestibility. Diets had no effect on $\mathrm{OM}, \mathrm{N}$, and NDF digestibility.

Both MCP and LCP diets resulted in lower excretion of urinary N compared with the control (Table 4); LCP tended to have lower $(P=0.06)$ excretion of urinary $\mathrm{N}$ compared with MCP. As a proportion of N intake, urinary $\mathrm{N}$ excretion was the highest with $\mathrm{HCP}$ and lowest with LCP, with MCP being intermediate. Excretion of urinary $\mathrm{N}$ as a proportion of total $\mathrm{N}$ excreted in urine and feces tended to be lower $(P=0.09)$ for LCP versus HCP. Diets did not affect total fecal N excretion. Total fecal and urinary $\mathrm{N}$ losses were lower for MCP and LCP compared with the control. As a proportion of $\mathrm{N}$ intake, excreta $\mathrm{N}$ losses were similar among diets.

Overall, diets did not affect ${ }^{15} \mathrm{~N}$ enrichment of ruminal ammonia $\mathrm{N}$ and bacterial $\mathrm{N}$ within $24 \mathrm{~h}$ following the ${ }^{15} \mathrm{~N}$ dose (Table 5). Treatment $\times$ time of sampling interactions were significant for these $\mathrm{N}$ pools; at time $0 \mathrm{~h},{ }^{15} \mathrm{~N}$ enrichment of ammonia $\mathrm{N}$ and $\mathrm{BN}$ were lower $(P<0.05)$ for HCP compared with MCP and LCP. Overall enrichment of MPN (Figure 2) was greater for MCP and LCP compared with the control. There was no treatment $\times$ time interaction for MPN ${ }^{15} \mathrm{~N}$ enrichment. Areas under the ${ }^{15} \mathrm{~N}$ curve for ruminal ammonia $\mathrm{N}, \mathrm{BN}$, and MPN were greater for MCP and LCP compared with HCP. The cumulative secretion of ${ }^{15} \mathrm{~N}$ in milk protein during the $143 \mathrm{~h}$ of milk sampling was greater for MCP and LCP compared with HCP (Figure 3 ). The theoretical maximum of ${ }^{15} \mathrm{~N}$ secreted in milk protein was greater (by 30\%) for LCP compared with $\mathrm{HCP}$. The proportions of $\mathrm{BN}$ originating from ammonia $\mathrm{N}$, and MPN originating from ammonia and BN were similar among diets, except that the LCP diet tended to have a lower $(P=0.05$ to 0.04$)$ proportion of $\mathrm{BN}$ and consequently MPN originating from ammonia $\mathrm{N}$ compared with MCP. The irreversible loss of ruminal ammonia $\mathrm{N}$ was lower for MCP and LCP compared with the HCP diet. As a proportion of $\mathrm{N}$ intake, the irreversible ammonia $\mathrm{N}$ loss was similar among diets. Diets did not affect the estimated utilization of ruminal ammonia $\mathrm{N}$ for microbial protein synthesis.

The cumulative ammonia $\mathrm{N}$ losses from manure (ammonia-emitting potential of manure) during the 15-d simulated postcollection storage period in a closedchamber system were the lowest for LCP and highest for HCP (Figure 4). The end-point (d 15) cumulative ammonia $\mathrm{N}$ emission was the lowest $(1,418 \mathrm{mg}$ ) for LCP and highest $(2,278 \mathrm{mg})$ for HCP. The rates of ammonia $\mathrm{N}$ emissions ( 83 to $138 \mathrm{mg} / \mathrm{d}$ ) were also lower for MCP and LCP relative to the control. Although the treatment $\times$ time interaction was significant, ammonia $\mathrm{N}$ emissions were consistently lower for the RDP-deficient diets compared with the control (Figure 4). 


\section{DISCUSSION}

At the DMI observed during the experiment and based on analyzed feed composition (NRC, 2001), both MCP and LCP were RDP deficient, and diet HCP had an estimated MP balance of $323 \mathrm{~g} / \mathrm{d}$. Several deficiencies of the NRC (2001) system require consideration when determining protein needs of the lactating cow and have been recently discussed in the context of a large (more than 1,700 diets) meta-analysis (Huhtanen and Hristov, 2009). These include inaccurate estimation of dietary RDP (and as a consequence, RUP) and the lack of accounting for urea $\mathrm{N}$ recycled to the gut. Because of these deficiencies, Huhtanen and Hristov (2009) concluded that protein degradability, as estimated by
NRC (2001), had no influence on milk protein yield or milk $\mathrm{N}$ efficiency. In a recent study at Pennsylvania State University, NRC (2001) underestimated milk yield (with no effect on milk components) by 7 to 9 $\mathrm{kg} / \mathrm{d}$ because of a combination of the above-mentioned deficiencies of the model [C. Lee (Pennsylvania State University, University Park, PA) and A. N. Hristov; unpublished data]. Energy did not limit production in any of the diets, although the NRC (2001) model states that energy estimates may be erroneous when the diet is deficient in RDP. Concentrations of Lys and Met and the ratio of the 2 essential amino acids in MP were also similar among diets (ratios of $3.5: 1$ to $3.6: 1$ ). Milk protein concentrations were relatively low in this experiment, which may have been caused by the lower

Table 2. Effect of dietary CP concentration and ruminally degraded protein intake on rumen fermentation and urinary excretion of purine derivatives in dairy cows (least squares means; $\mathrm{n}=180$, rumen $\mathrm{pH}$ and ammonia data; $\mathrm{n}=90$, rumen methane; $\mathrm{n}=17$, urinary data; and $\mathrm{n}=18$, all other variables)

\begin{tabular}{|c|c|c|c|c|c|}
\hline Item & High CP & Medium CP & Low CP & SEM & $P=$ \\
\hline \multicolumn{6}{|l|}{ Rumen } \\
\hline $\mathrm{pH}$ & $6.45^{\mathrm{a}}$ & $6.38^{\mathrm{b}}$ & $6.36^{\mathrm{b}}$ & 0.051 & $0.024^{1}$ \\
\hline $\mathrm{NH}_{3}, \mathrm{~m} M$ & $7.0^{\mathrm{a}}$ & $5.0^{\mathrm{b}}$ & $5.3^{\mathrm{b}}$ & 0.20 & $<0.001^{2}$ \\
\hline Rumen $\mathrm{NH}_{3} \mathrm{~N}$ pool $(0 \mathrm{~h}){ }_{2}^{3} \mathrm{~g}$ & 7.1 & 5.2 & 6.6 & 0.62 & $0.067^{4}$ \\
\hline Rumen $\mathrm{NH}_{3} \mathrm{~N}$ pool, ${ }^{5} \mathrm{~g}$ & $13.2^{\mathrm{a}}$ & $10.4^{\mathrm{b}}$ & $9.2^{\mathrm{b}}$ & 1.09 & 0.044 \\
\hline Total free AA, $\mathrm{m} M$ & $5.2^{\mathrm{a}}$ & $3.8^{\mathrm{b}}$ & $4.1^{\mathrm{b}}$ & 0.31 & 0.016 \\
\hline Total VFA, $\mathrm{m} M$ & 93.3 & 93.8 & 92.0 & 2.50 & 0.81 \\
\hline Acetate & 61.4 & 61.0 & 60.4 & 1.79 & 0.89 \\
\hline Propionate & 18.0 & 18.3 & 17.6 & 0.63 & 0.70 \\
\hline Isobutyrate & $1.02^{\mathrm{a}}$ & $0.96^{\mathrm{a}}$ & $0.87^{\mathrm{b}}$ & 0.044 & 0.022 \\
\hline Butyrate & 8.8 & 9.3 & 8.9 & 0.51 & 0.53 \\
\hline Isovalerate & 1.74 & 1.60 & 1.60 & 0.128 & 0.59 \\
\hline Valerate & 2.33 & 2.56 & 2.69 & 0.143 & 0.24 \\
\hline Acetate:propionate & 3.4 & 3.4 & 3.5 & 0.15 & 0.79 \\
\hline \multicolumn{6}{|l|}{ PSD activities ${ }^{6}$} \\
\hline CMCase & 89.8 & 93.6 & 99.6 & 20.28 & 0.95 \\
\hline Xylanase & 102.9 & 107.2 & 157.8 & 32.55 & 0.49 \\
\hline Amylase & 72.3 & 89.9 & 87.4 & 6.82 & 0.20 \\
\hline Methane production rate, $\mathrm{g} / \mathrm{h}$ & 4.1 & 2.9 & 2.3 & 0.95 & $0.51^{7}$ \\
\hline Liquid phase FOR, ${ }^{8} \% / \mathrm{h}$ & 12.0 & 11.5 & 11.8 & 0.80 & 0.89 \\
\hline \multicolumn{6}{|l|}{ Urinary $\mathrm{PD},{ }^{9} \mathrm{mmol} / \mathrm{d}$} \\
\hline Allantoin & 466 & 387 & 389 & $29.2^{10}$ & 0.18 \\
\hline Uric acid & 57 & 44 & 44 & $4.1^{10}$ & 0.08 \\
\hline Total PD & 523 & 431 & 434 & $33.0^{10}$ & 0.16 \\
\hline $\mathrm{MN},{ }^{11} \mathrm{~g} / \mathrm{d}$ & 351 & 282 & 284 & $24.3^{10}$ & 0.16 \\
\hline
\end{tabular}

${ }^{\mathrm{a}, \mathrm{b}}$ Within a row, means without a common superscript letter differ $(P<0.05)$.

${ }^{1}$ Treatment $\times$ time interaction, $P=0.87$.

${ }^{2}$ Treatment $\times$ time interaction, $P=0.001$.

${ }^{3}$ Rumen ammonia $\mathrm{N}$ pool size $(\mathrm{g})$ at time $0 \mathrm{~h}$ estimated from ruminal evacuation data and ammonia concentration in ruminal fluid.

${ }^{4}$ High CP vs. medium CP, $P=0.028$.

${ }^{5}$ Rumen ammonia $\mathrm{N}$ pool size (g) estimated based on ${ }^{15} \mathrm{~N}$ kinetics (see Materials and Methods).

${ }^{6} \mathrm{PSD}=$ polysaccharide-degrading activities. Expressed as nanomoles of reducing sugars as glucose released per milliliter of ruminal fluid per minute; CMCase = carboxymethylcellulase.

${ }^{7}$ Treatment $\times$ time interaction, $P=0.31$.

${ }^{8} \mathrm{FOR}=$ fractional outflow rate.

${ }^{9}$ Excretion of urinary purine derivatives (PD).

${ }^{10}$ High CP, $\mathrm{SE}=32.4,4.5,36.6$, and 26.9, respectively.

${ }^{11}$ Estimated microbial $\mathrm{N}$ outflow from the rumen [based on urinary PD excretion; see Materials and Methods]. 


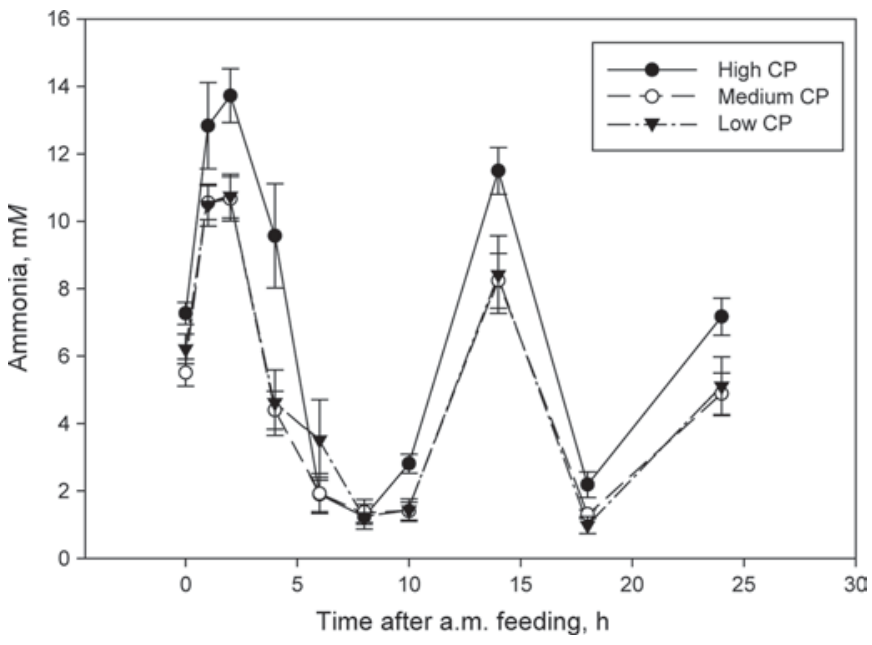

Figure 1. Effect of dietary $\mathrm{CP}$ concentration and ruminally degraded protein intake on ruminal ammonia concentration in dairy cows (means $\pm \mathrm{SE} ; \mathrm{n}=180$ ). Overall treatment effect, $P<0.001$; treatment $\times$ time interaction, $P=0.001$. than recommended Met concentration in MP. Based on NRC-predicted MP and $\mathrm{NE}_{\mathrm{L}}$ supply, an effect of the RDP-deficient diets on production was not expected. It has to be noted, however, that the design (Latin square) and duration of this experiment were not appropriate to study production effects, and responses to low CP diets may be different in a larger scale lactation study. In addition, higher producing cows may have responded differently to a reduction in dietary CP supply. In other studies, reduced dietary $\mathrm{CP}$ and RDP concentrations did not negatively affect production (Olmos Colmenero and Broderick, 2006) and when such an effect was reported (Broderick, 2003, for example), it was a result of reduced DMI with the low CP diets.

The RDP-deficient diets had no effect on ruminal fermentation other than decreased ammonia and TFAA concentrations and $\mathrm{pH}$, with the latter most likely resulting from the greater concentration of NFC (from corn silage and grain) with these diets compared with

Table 3. Effect of dietary CP concentration and ruminally degraded protein intake on milk yield and composition, plasma urea $\mathrm{N}$ concentration, BW, nutrient intake, and total-tract apparent digestibility of nutrients in dairy cows (least squares means; $\mathrm{n}=18$ )

\begin{tabular}{lccccc}
\hline Item & High CP & Medium CP & Low CP & SEM & $P=$ \\
\hline Milk yield, kg/d & 30.8 & 31.6 & 30.2 & 2.50 & 0.45 \\
Milk/DMI & 1.22 & 1.33 & 1.28 & 0.067 & 0.13 \\
Milk fat, \% & 3.43 & 3.39 & 3.47 & 0.096 & 0.59 \\
Yield, kg/d & 1.05 & 1.07 & 1.04 & 0.077 & 0.88 \\
4\% FCM, kg/d & 28.1 & 28.7 & 27.7 & 2.10 & 0.72 \\
Milk true protein, \% & 2.87 & 2.91 & 2.92 & 0.108 & 0.16 \\
Yield, kg/d & 0.88 & 0.91 & 0.88 & 0.063 & 0.46 \\
N yield, kg/d & 0.138 & 0.143 & 0.138 & 0.0099 & 0.48 \\
As \% of N intake & $22.3^{\mathrm{b}}$ & $28.0^{\mathrm{a}}$ & $28.2^{\mathrm{a}}$ & 0.97 & $<0.001$ \\
Milk lactose, \% & 4.76 & 4.79 & 4.76 & 0.121 & 0.56 \\
Milk NE yield, ${ }^{2}$ Mcal/d & 20.5 & 21.1 & 20.3 & 1.59 & 0.64 \\
MUN, mg/100 mL & $14.4^{\mathrm{a}}$ & $10.8^{\mathrm{b}}$ & $10.3^{\mathrm{b}}$ & 0.69 & $<0.001$ \\
PUN, ${ }^{3}$ mg/100 mL & $15.8^{\mathrm{a}}$ & $14.8^{\mathrm{a}}$ & $11.7^{\mathrm{b}}$ & 0.94 & 0.021 \\
BW, kg ing & 664 & 656 & 673 & 22.7 & $0.08^{4}$ \\
Nutrient intake, kg/d & & & & 1.44 & 0.15 \\
DM & 25.2 & 23.6 & 23.7 & 1.30 & 0.23 \\
OM & 22.8 & 21.7 & 21.7 & 0.0332 & $<0.001$ \\
N & $0.620^{\mathrm{a}}$ & $0.509^{\mathrm{b}}$ & $0.487^{\mathrm{b}}$ & 0.45 & $0.09^{5}$ \\
NDF & 7.9 & 7.3 & 7.4 & 0.41 & $<0.001$ \\
Starch & $6.9^{\mathrm{a}}$ & $5.2^{\mathrm{c}}$ & $6.4^{\mathrm{b}}$ & & \\
Apparent digestibility, \% & & & & & \\
DM & 69.2 & 62.7 & 67.5 & 1.51 & $0.06^{6}$ \\
OM & 70.8 & 73.3 & 71.1 & 1.49 & 0.52 \\
N & 69.1 & 69.4 & 65.9 & 1.96 & 0.51 \\
NDF & 53.0 & 56.7 & 53.9 & 2.16 & 0.45 \\
Starch & 89.9 & 87.7 & 89.7 & 0.69 & $0.08^{7}$ \\
\hline
\end{tabular}

${ }^{a-c}$ Within a row, means without a common superscript letter differ $(P<0.05)$.

${ }^{1}$ Milk true protein yield $\div 6.38$.

${ }^{2}$ Milk NE yield $(\mathrm{Mcal} / \mathrm{d})=$ milk yield, $\mathrm{kg} / \mathrm{d} \times(0.0929 \times$ milk fat, $\%+0.0563 \times$ milk true protein, $\%+0.0395$

$\times$ milk lactose, \%); based on NRC (2001).

${ }^{3}$ Blood plasma urea N.

${ }^{4}$ High $\mathrm{CP}$ vs. low $\mathrm{CP}, P=0.04$; medium $\mathrm{CP}$ vs. low $\mathrm{CP}, P=0.07$.

${ }^{5}$ High $\mathrm{CP}$ vs. medium $\mathrm{CP}, P=0.04$.

${ }^{6}$ High CP vs. medium CP, $P=0.03$; medium CP vs. low CP, $P=0.08$.

${ }^{7}$ High CP vs. medium CP, $P=0.04$; medium CP vs. low $\mathrm{CP}, P=0.06$. 
Table 4. Effect of dietary CP concentration and ruminally degraded protein intake on urinary and fecal N losses in dairy cows (least squares means; fecal data, $\mathrm{n}=18$; urine data $\mathrm{n}=17$ )

\begin{tabular}{|c|c|c|c|c|c|}
\hline Item & High CP & Medium CP & Low CP & SEM & $P=$ \\
\hline \multicolumn{6}{|l|}{ Urinary $\mathrm{N}$} \\
\hline $\mathrm{kg} / \mathrm{d}$ & $0.188^{\mathrm{a}}$ & $0.133^{\mathrm{b}}$ & $0.115^{\mathrm{b}}$ & $0.0078^{1}$ & $<0.001^{2}$ \\
\hline As $\%$ of $N$ intake & $29.3^{\mathrm{a}}$ & $26.0^{\mathrm{b}}$ & $23.8^{\mathrm{c}}$ & $0.94^{1}$ & 0.003 \\
\hline As $\%$ of total $\mathrm{N}$ excreted & 50.3 & 46.0 & 41.5 & $2.03^{1}$ & $0.09^{3}$ \\
\hline \multicolumn{6}{|l|}{ Fecal N } \\
\hline $\mathrm{kg} / \mathrm{d}$ & 0.188 & 0.155 & 0.169 & 0.0123 & 0.15 \\
\hline As $\%$ of $\mathrm{N}$ intake & 30.9 & 30.6 & 34.1 & 1.96 & 0.51 \\
\hline \multicolumn{6}{|l|}{ Total N excretion } \\
\hline $\mathrm{kg} / \mathrm{d}$ & $0.375^{\mathrm{a}}$ & $0.287^{\mathrm{b}}$ & $0.283^{\mathrm{b}}$ & $0.0161^{4}$ & 0.001 \\
\hline As $\%$ of $\mathrm{N}$ intake & 58.5 & 56.7 & 57.9 & $1.60^{3}$ & 0.78 \\
\hline
\end{tabular}

${ }^{\mathrm{a}-\mathrm{c}}$ Within a row, means without a common superscript letter differ $(P<0.05)$.

${ }^{1} \mathrm{High} \mathrm{CP}, \mathrm{SE}=0.0085,1.01$, and 2.24, respectively.

${ }^{2}$ Medium CP vs. low CP, $P=0.06$.

${ }^{3}$ High CP vs. low CP, $P=0.03$.

${ }^{4} \mathrm{High} \mathrm{CP}, \mathrm{SE}=0.0172$ and 1.74 , respectively.

the control diet (HCP). The lowered ammonia concentration with low-CP diets was expected and has been reported in most, but not all (Wattiaux and Karg, 2004), studies in which dietary CP (or RDP) was a main effect (Davidson et al., 2003; Reynal and Broderick, 2005; Olmos Colmenero and Broderick, 2006). Corresponding effects on plasma urea $\mathrm{N}$ and MUN are also typically reported for diets with reduced $\mathrm{CP}$ and RDP (Davidson et al., 2003; Hristov et al., 2004; Olmos Colmenero and Broderick, 2006) and were similarly observed in the cur- rent study. Concentration of ammonia in ruminal fluid is a function of ammonia production (deamination of amino acids, intensified when energy is limited; Russell et al., 1983), ammonia uptake by the ruminal microorganisms, and diffusion through the rumen wall. As we have demonstrated (Hristov et al., 2005), reduced ammonia production and enhanced uptake may result in similar reductions in ruminal ammonia concentration. In this study, diets did not seem to affect ammonia uptake by ruminal bacteria (Table 5), suggesting that

Table 5. Effect of dietary $\mathrm{CP}$ concentration and ruminally degraded protein intake on ${ }^{15} \mathrm{~N}$ enrichment of various $\mathrm{N}$ pools and ${ }^{15} \mathrm{~N}$ calculations in dairy cows (least squares means; $\mathrm{n}=414,{ }^{15} \mathrm{~N}$ enrichment of MPN; $\mathrm{n}=173,{ }^{15} \mathrm{~N}$ enrichment of $\mathrm{NH}_{3} \mathrm{~N}$ and $\mathrm{BN}$; and $\mathrm{n}=18$, all other variables)

\begin{tabular}{|c|c|c|c|c|c|}
\hline Item & High CP & Medium CP & Low CP & SEM & $P=$ \\
\hline${ }^{15} \mathrm{~N}$ enrichment of $\mathrm{BN},{ }^{3} \mathrm{APE}$ & 0.114 & 0.139 & 0.147 & 0.0141 & $0.24^{2}$ \\
\hline${ }^{15} \mathrm{~N}$ enrichment of $\mathrm{MPN},{ }^{4} \mathrm{APE}$ & $0.0089^{\mathrm{b}}$ & $0.0110^{\mathrm{a}}$ & $0.0107^{\mathrm{a}}$ & 0.0004 & $0.008^{2}$ \\
\hline $\mathrm{AUC}, \mathrm{BN}$ & $1.87^{\mathrm{b}}$ & $2.35^{\mathrm{a}}$ & $2.40^{\mathrm{a}}$ & 0.083 & $<0.001$ \\
\hline AUC, MPN & $1.09^{\mathrm{b}}$ & $1.36^{\mathrm{a}}$ & $1.30^{\mathrm{a}}$ & 0.053 & $<0.001$ \\
\hline $\mathrm{BN}$ from $\mathrm{NH}_{3} \mathrm{~N}^{6}{ }^{\%} \%$ & 49.0 & 50.6 & 46.2 & 2.79 & $0.13^{7}$ \\
\hline Irreversible loss of ruminal $\mathrm{NH}_{3} \mathrm{~N}, \mathrm{~g} \mathrm{~N} / \mathrm{d}$ & $345^{\mathrm{a}}$ & $286^{\mathrm{b}}$ & $254^{\mathrm{b}}$ & 24.8 & 0.008 \\
\hline As $\%$ of $\mathrm{N}$ intake & 56.1 & 56.5 & 52.7 & 3.94 & 0.41 \\
\hline Utilization of ruminal $\mathrm{NH}_{3} \mathrm{~N}$ for microbial protein synthesis, ${ }^{9} \%$ & 49.3 & 50.3 & 52.1 & 4.57 & 0.91 \\
\hline
\end{tabular}

${ }^{\mathrm{a}, \mathrm{b}}$ Within a row, means without a common superscript letter differ $(P<0.05)$.

${ }^{1}$ Atom percent excess.

${ }^{2}$ Treatment $\times$ time interactions: $\mathrm{NH}_{3} \mathrm{~N}, P<0.001 ; \mathrm{BN}, P=0.046 ; \mathrm{MNP}, P=0.38$.

${ }^{3}$ Bacterial N.

${ }^{4}$ Milk protein $\mathrm{N}$.

${ }^{5}$ Area under the ${ }^{15} \mathrm{~N}$ curve, APE $\times \mathrm{h}$.

${ }^{6}$ Calculated as $\left(\mathrm{AUC}_{\text {rumen bacteria }} \div \mathrm{AUC}_{\text {rumen ammonia }}\right) \times 100 ;\left(\mathrm{AUC}_{\text {milk protein }} \div \mathrm{AUC}_{\text {rumen bacteria }}\right) \times 100$; or $\left(\mathrm{AUC}\right.$ milk protein $\left.\div \mathrm{AUC}_{\text {rumen ammonia }}\right) \times 100$, respectively.

${ }^{7}$ Medium CP vs. low CP, $P=0.05$.

${ }^{8}$ Medium CP vs. low $\mathrm{CP}, P=0.04$.

${ }^{9}$ Proportion of the irreversible loss of ammonia $\mathrm{N}$ leaving the rumen as microbial $\mathrm{N}$. Calculated as [(MN flow $\times$ proportion of bacterial $\mathrm{N}$ derived from ammonia $\mathrm{N}) \div$ irreversible loss of ammonia $\mathrm{N}] \times 100$. 


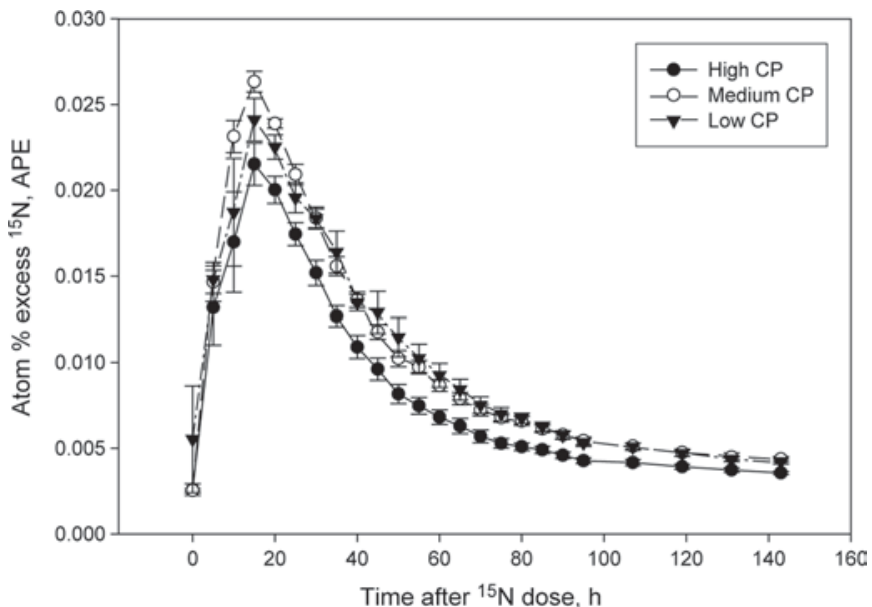

Figure 2. Effect of dietary $\mathrm{CP}$ concentration and ruminally degraded protein intake on ${ }^{15} \mathrm{~N}$-enrichment of milk protein $\mathrm{N}$ in dairy cows (means $\pm \mathrm{SE} ; \mathrm{n}=414$ ). Overall treatment effect, $P=0.008$ treatment $\times$ time interaction, $P=0.38$.

the most likely explanation for the reduced ammonia concentration is an overall reduction in proteolysis of dietary proteins, because of availability, and consecutive reduction of amino acid deamination, supported by the lower TFAA concentration with the RDP-deficient diets. Diets did not differ in the amount of microbial protein reaching the small intestine. Urea recycling to the digestive tract can be a significant source of RDP

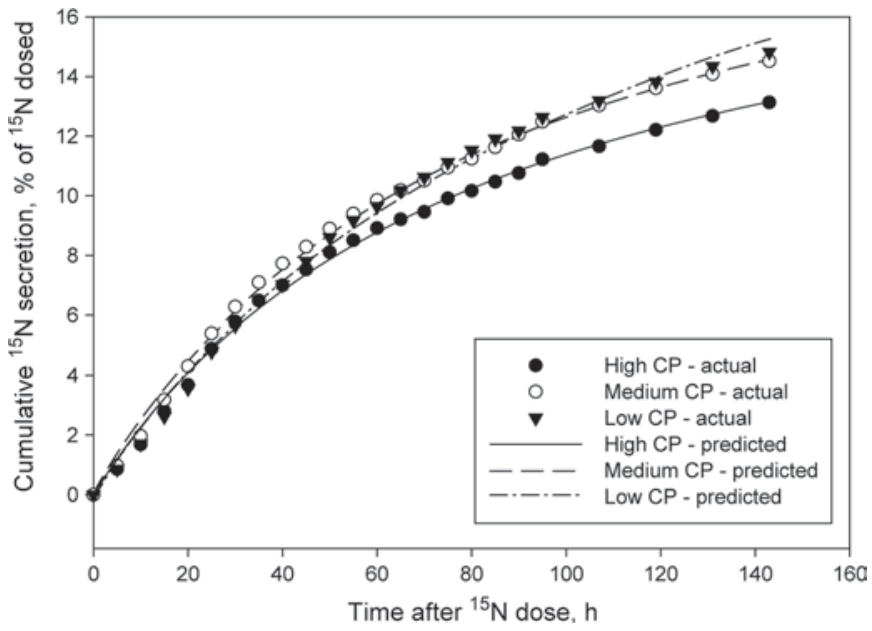

Figure 3. Effect of dietary $\mathrm{CP}$ concentration and ruminally degraded protein intake on cumulative secretion of ${ }^{15} \mathrm{~N}$ in milk protein (as percentage of ${ }^{15} \mathrm{~N}$ dosed intraruminally). Symbols are measured and lines are predicted values (single rectangular 2-parameter hyperbola model). Theoretical maximum of ${ }^{15} \mathrm{~N}$ secreted in milk (as \% of dosed; estimate \pm approximate SE; $\mathrm{n}=432$ ): $20.6 \pm 1.58,23.0 \pm 1.70$, and $27.0 \pm 2.45$, for high, medium, and low $\mathrm{CP}$, respectively (high vs. medium $\mathrm{CP}, P=0.32$; high vs. low $\mathrm{CP}, P=0.032$; medium vs. low $\mathrm{CP}, P=0.17)$. Differences between ${ }^{15} \mathrm{~N}$ secretion lines: high vs. medium $\mathrm{CP}, P<0.001$; high vs. low $\mathrm{CP}, P<0.001$; medium vs. low $\mathrm{CP}, P=0.37$.

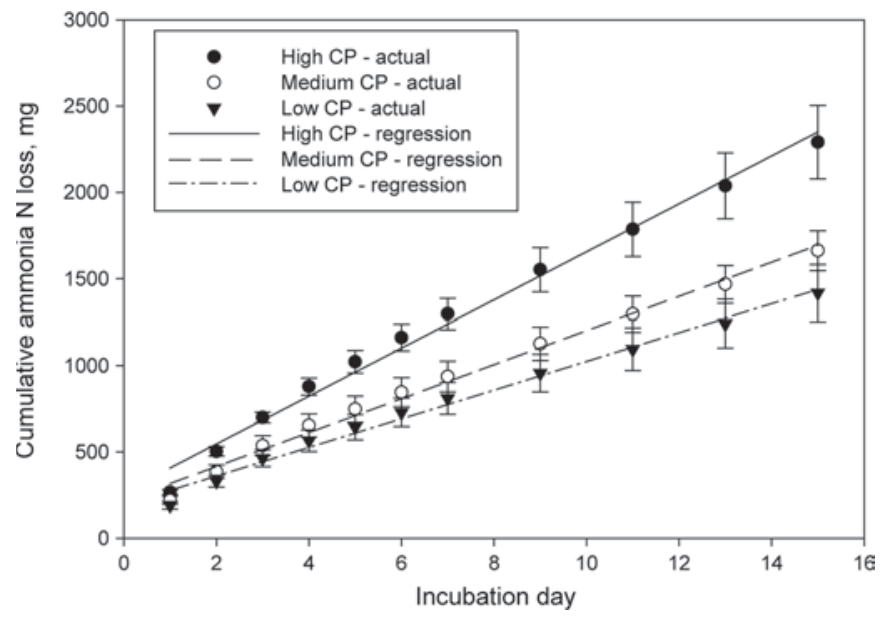

Figure 4. Effect of dietary $\mathrm{CP}$ concentration and ruminally degraded protein intake on cumulative ammonia $\mathrm{N}$ losses from dairy manure. Symbols are measured (means $\pm \mathrm{SE}$ ) and lines are predicted values (linear regression). End-point (d 15) cumulative ammonia N emission ( $\mathrm{n}=15 ; P=0.001$ ): $2,278,1,673$, and $1,418 \mathrm{mg}$ (for high, medium, and low $\mathrm{CP}$, respectively; $\mathrm{SEM}=188.1$; high vs. medium $\mathrm{CP}$, $P=0.003$; high vs. low $\mathrm{CP}, P<0.001$; medium vs. low $\mathrm{CP}, P=0.09$ ). Regression analysis $(\mathrm{n}=165)$ : diet effect, $P<0.001$; diet $\times$ incubation day interaction, $P<0.001$. Slope: 138,98 , and $83 \mathrm{mg}$ of ammonia N/d (for high, medium, and low $\mathrm{CP}$, respectively; $\mathrm{SEM}=6.97$ ); high vs. medium $\mathrm{CP}, P<0.001$; high vs. low $\mathrm{CP}, P=0.11$; medium vs. low $\mathrm{CP}, P<0.001$. Regression lines: high vs. medium $\mathrm{CP}, P<0.001$; high vs. low $\mathrm{CP}, P=0.004$; medium vs. low $\mathrm{CP}, P<0.001$.

for ruminal microbes (Lapierre and Lobley, 2001; Reynolds and Kristensen, 2008) and likely has compensated, partially or completely, for the RDP deficiency with the MCP and LCP diets in this study.

Reduced urinary $\mathrm{N}$ excretion was typically observed when low $\mathrm{CP}$ and RDP diets were fed to dairy cows (Haig et al., 2002; Hristov et al., 2004; Olmos Colmenero and Broderick, 2006). As reported in the current study, this could also be reflected in greater total (fecal and urinary) N losses (Groff and Wu, 2005; Reynal and Broderick, 2005). Reduction in relative urinary and fecal $\mathrm{N}$ losses is expected to enhance the efficiency of conversion of dietary $\mathrm{N}$ into milk protein; in this study, MCP and LCP resulted in about $27 \%$ greater MNE compared with the control. Meta-analysis demonstrated that among several dietary and animal performance variables, dietary $\mathrm{CP}$ was the most important factor determining MNE in dairy cows (Huhtanen and Hristov, 2009). Variability in milk yield may explain some of the variability in MNE when included in a model with dietary CP, but was insignificant as a stand-alone prediction variable. Our estimations have shown that increasing dietary $\mathrm{CP}$ concentration by 1 percentage unit may increase milk protein $\mathrm{N}$ yield by approximately $2.8 \mathrm{~g} / \mathrm{d}$, but will result in $35.7 \mathrm{~g} / \mathrm{d}$ dietary $\mathrm{N}$ not being utilized for milk protein synthesis (Hristov and Huhtanen, 2008). A major fraction of this unaccounted 
$\mathrm{N}$ will be excreted in urine, which is more susceptible to leaching and evaporative losses than fecal N (Bussink and Oenema, 1998). Huhtanen et al. (2008), for example, using a data set of mainly grass silage-based diets, estimated that $84 \%$ of the incremental $\mathrm{N}$ intake at constant DMI is excreted in urine.

Diet had a pronounced effect on ${ }^{15} \mathrm{~N}$-ammonia kinetics. Clearly, the AUC for the ruminal $\mathrm{N}$ pool studied and MPN were larger for the RDP-deficient diets compared with HCP. The amount of ammonia $\mathrm{N}$ added to the ruminal ammonia pool (with ${ }^{15} \mathrm{NH}_{4} \mathrm{Cl}$ ) at time $0 \mathrm{~h}$ was $0.55 \mathrm{~g}$, which represented from 8 ( $\mathrm{HCP}$ and LCP) to $11 \%$ (MCP) of ruminal ammonia $\mathrm{N}$ before feeding, based on rumen evacuation data, and would be significantly less after feeding (4 to $6 \%$, based on the isotope dilution data). Thus, the labeled ammonia $\mathrm{N}$ added to the rumen was unlikely to have a significant effect on the natural pattern of ammonia metabolism in this experiment. As the size of ruminal ammonia $\mathrm{N}$ pool was smaller in MCP and LCP (compared with $\mathrm{HCP}$ ), the greater AUC of ammonia $\mathrm{N}$ with the former diets was expected. This and the similar proportion of $\mathrm{BN}$ originating from ruminal ammonia $\mathrm{N}$ could explain the greater AUC of bacterial $\mathrm{N}$ with the RDP-deficient diets. Consequently, the AUC of MPN was also greater for the RDP-deficient diets because of the similar proportion of MPN originating from $\mathrm{BN}$ and the greater AUC for these diets. Thus, in spite of similar transfer efficiencies between ruminal $\mathrm{N}$ pools and MPN, proportionally more (15 and $35 \%$ more for MCP and LCP, respectively; Figure 3) of the labeled ammonia $\mathrm{N}$ introduced into the rumen at $0 \mathrm{~h}$ was secreted in milk protein with the RDP-deficient diets compared with the control. This clearly indicates a more efficient conversion of ruminal ammonia $\mathrm{N}$ into milk protein when RDP-deficient diets are fed to dairy cows. The predicted maximum recovery of ${ }^{15} \mathrm{~N}$ in milk protein was greater in this experiment ( 20 to $27 \%$ of dose) than in our previous studies (12 to 14\%, Hristov et al., 2005; 16 to $18 \%$, Hristov et al., 2009a), primarily influenced by the low dietary $\mathrm{CP}$ content in the current study, but also by the duration of milk sampling and milk yield of the cows (Hristov et al., 2003).

Compared with the control, both RDP-deficient diets remarkably reduced the ammonia-emitting potential of manure. The spatial variation of ammonia concentrations is a major technical difficulty in accurate determination of ammonia losses in animal facilities (Hristov et al., 2009b), which is reflected in the wide range of ammonia emission data reported in the literature (Ndegwa et al., 2008; $\mathrm{Ni}$ and Heber, 2008; Li et al., 2009). Thus, an estimation of the ammonia-emitting potential of manure under controlled laboratory conditions is likely to provide a more reliable analysis of the potential ammonia losses from manure in the field and how management practices (including diet composition) may affect it. European researchers have reported a significant reduction in ammonia (and nitrous oxide) emissions from manure as a result of lowering dietary CP and RDP (Külling et al., 2001; Van Duinkerken et al., 2005). In some cases, however, dietary CP did not affect ammonia emissions (Misselbrook et al., 2005; Powell et al., 2008), in spite of the fact that in both studies urinary $\mathrm{N}$ excretion was 2-fold greater with the high (19 or $21 \%$ ) versus low (14 or $17 \%$ ) CP diets. A more recent study ( $\mathrm{Li}$ et al., 2009) also reported no effect of dietary CP concentration (17.8 vs. 15.9\%) on ammonia emissions from the barn floor of a dairy facility ( 2.7 to $2.9 \mathrm{~g}$ of $\mathrm{N} / \mathrm{cow}$ per day), although emissions were reduced from manure storage tanks ( $\mathrm{Li}$ et al., 2008). Perhaps the most comprehensive study to date investigating effect of dietary variables on ammonia emission from dairy manure was conducted at The Ohio State University (Weiss et al., 2009). This researcher found that increasing dietary MP (15 diets varying in type of forage, starch, and MP content were examined) increased ammonia $\mathrm{N}$ produced per gram of manure (determined in a laboratory-scale, closedchamber system), mainly because of increased urinary $\mathrm{N}$ excretion with a significantly smaller contribution of fecal N. Although effects of dietary CP or RDP were not reported, the effect of MP is in agreement with results from the current study (excess RDP in HCP was accompanied by an excess in MP).

\section{CONCLUSIONS}

This study demonstrated that dairy cow diets with reduced $\mathrm{CP}$ and RDP concentrations resulted in manure with significantly lower ammonia-emitting potential without affecting cow performance, when the MP requirements of the cows were met. The effect on ammonia losses from manure was a consequence of reduced urinary $\mathrm{N}$ excretion and proportion of urinary $\mathrm{N}$ of the total excreta N. Lowering RDP concentration in the diet improved the efficiency of utilization of ruminal ammonia $\mathrm{N}$ for milk protein synthesis.

\section{ACKNOWLEDGMENTS}

This study was supported by funds from the Idaho Dairymen Association and University of Idaho Agricultural Experiment Station. The authors thank V. Borek (Department of Plant, Soil, and Entomological Sciences, University of Idaho, Moscow) for conducting the methane analyses, W. Price (Statistical Programs, College of Agricultural and Life Sciences, University of Idaho, Moscow) for assistance with statistical evalua- 
tion of the results, and the staff of the Department of Animal and Veterinary Science Dairy Center for their conscientious care of the experimental cows.

\section{REFERENCES}

AOAC. 2000. Official Methods of Analysis. 17th ed. AOAC, Arlington, VA.

APHA. 1998. Standard Methods for the Examination of Water and Wastewater. 20th ed. S. C. Lenore, A. E. Greenberg, and A. D. Eaton, ed. American Public Health Association, Washington, DC

Bergman, E. N., and R. N. Heitmann. 1978. Metabolism of amino acids by the gut, liver, kidneys, and peripheral tissues. Fed. Proc. 37:1228-1232.

Broderick, G. A. 2003. Effect of varying dietary protein and energy levels on the production of lactating dairy cows. J. Dairy Sci. $86: 1370-1381$.

Broderick, G. A., and N. R. Merchen. 1992. Markers for quantifying microbial protein synthesis in the rumen. J. Dairy Sci. 75:26182632.

Bussink, D. W., and O. Oenema. 1998. Ammonia volatilization from dairy farming systems in temperate areas: A review. Nutr. Cycl. Agroecosyst. 51:19-33.

Chen, X. B. 1989. Excretion of purine derivatives by sheep and cattle and its use for estimation of absorbed microbial protein. $\mathrm{PhD}$ Thesis. University of Aberdeen, UK.

Chen, X. B., Y. K. Chen, M. F. Franklin, E. R. Ørskov, and W. J. Shand. 1992. The effect of feed intake and body weight on purine derivative excretion and microbial protein supply in sheep. J. Anim. Sci. 70:1534-1542.

Cochran, W. G., and G. M. Cox. 1992. Experimental Designs. 2nd ed. John Wiley \& Sons Inc., Hoboken, NJ.

Davidson, S., B. A. Hopkins, D. E. Diaz, S. M. Bolt, C. Brownie, V. Fellner, and L. W. Whitlow. 2003. Effects of amounts and degradability of dietary protein on lactation, nitrogen utilization, and excretion in early lactation Holstein cows. J. Dairy Sci. 86:1681-1689.

Ferguson, J. D., and D. Sklan. 2005. Effects of dietary phosphorus and nitrogen on cattle reproduction. Pages 233-253 in Nitrogen and Phosphorus Nutrition of Cattle and Environment. A. N. Hristov and E. Pfeffer, ed. CAB International, Wallingford, UK.

Foley, A. E., A. N. Hristov, A. Melgar, J. K. Ropp, R. P. Etter, S Zaman, C. W. Hunt, K. Huber, and W. J. Price. 2006. Effect of barley and its amylopectin content on ruminal fermentation and nitrogen utilization in lactating dairy cows. J. Dairy Sci. 89:4321-4335.

Frank, B., M. Persson, and G. Gustafsson. 2002. Feeding dairy cows for decreased ammonia emission. Livest. Prod. Sci. 76:171-179.

Groff, E. B., and Z. Wu. 2005. Milk production and nitrogen excretion of dairy cows fed different amounts of protein and varying proportions of alfalfa and corn silage. J. Dairy Sci. 88:36193632.

Haig, P. A., T. Mutsvangwa, R. Spratt, and B. W. McBride. 2002. Effects of dietary protein solubility on nitrogen losses from lactating dairy cows and comparison with predictions from the Cornell Net Carbohydrate and Protein System. J. Dairy Sci. 85:1208-1217.

Hristov, A. N., R. P. Etter, J. K. Ropp, and K. L. Grandeen. 2004 Effect of dietary crude protein level and degradability on ruminal fermentation and nitrogen utilization in lactating dairy cows. J. Anim. Sci. 82:3219-3229.

Hristov, A. N., W. Hazen, and J. W. Ellsworth. 2006. Nitrogen, phosphorus, and potassium balance and potentials for reducing phosphorus imports in Idaho dairy farms. J. Dairy Sci. 89:37023712 .

Hristov, A. N., and P. Huhtanen. 2008. Nitrogen efficiency in Holstein cows and dietary means to mitigate nitrogen losses from dairy operations. Pages 125-136 in Proc. Cornell Nutrition Conference, Syracuse, NY.
Hristov, A. N., T. A. McAllister, and K.-J. Cheng. 1998. Effect of dietary or abomasal supplementation of exogenous polysaccharidedegrading enzymes on rumen fermentation and nutrient digestibility. J. Anim. Sci. 76:3146-3156.

Hristov, A. N., T. A. McAllister, F. H. Van Herk, K.-J. Cheng, C. J. Newbold, and P. R. Cheeke. 1999. Effect of Yucca schidigera on ruminal fermentation and nutrient digestion in heifers. J. Anim. Sci. $77: 2554-2563$.

Hristov, A. N., and J. K. Ropp. 2003. Effect of dietary carbohydrate composition and availability on utilization of ruminal ammonia nitrogen for milk protein synthesis in dairy cows. J. Dairy Sci. 86:2416-2427.

Hristov, A. N., J. K. Ropp, K. L. Grandeen, S. Abedi, R. P. Etter, A. Melgar, and A. E. Foley. 2005. Effect of carbohydrate source on ammonia utilization in lactating dairy cows. J. Anim. Sci. $83: 408-421$

Hristov, A. N., J. K. Ropp, K. L. Grandeen, R. P. Etter, A. Foley, A. Melgar, and W. Price. 2003. Efficiency of utilization of ruminal ammonia $\mathrm{N}$ for milk protein synthesis in dairy cows. Pages 601604 in Progress in Research on Energy and Protein Metabolism, EAAP publication No. 109. W. B. Souffrant and C. C. Metges, ed Wageningen Academic Publishers, Wageningen, the Netherlands.

Hristov, A. N., M. Vander Pol, M. Agle, S. Zaman, C. Schneider, P. Ndegwa, V. K. Vaddella, K. Johnson, K. J. Shingfield, and S. K. R. Karnati. 2009a. Effect of lauric acid and coconut oil on ruminal fermentation, digestion, ammonia losses from manure, and milk fatty acid composition in lactating cows. J. Dairy Sci. 92:5561-5582.

Hristov, A. N., S. Zaman, M. Vander Pol, L. Campbell, P. Ndegwa, and S. Silva. 2009b. Nitrogen losses from dairy manure estimated through nitrogen mass balance or using markers. J. Environ. Qual. 38:2438-2448.

Huhtanen, P., and A. N. Hristov. 2009. A meta-analysis of the effects of protein concentration and degradability on milk protein yield and milk N efficiency in dairy cows. J. Dairy Sci. 92:3222-3232.

Huhtanen, P., J. I. Nousiainen, M. Rinne, K. Kytölä, and H. Khalili. 2008. Utilization of and partitioning of dietary nitrogen in dairy cows fed grass silage-based diets. J. Dairy Sci. 91:3589-3599.

Johnson, K. A., M. T. Huyler, H. H. Westberg, B. K. Lamb, and P. Zimmerman. 1994. Measurement of methane emissions from ruminant livestock using a $\mathrm{SF}_{6}$ tracer technique. Environ. Sci. Technol. 28:359-362.

Johnson, K. A., H. H. Westberg, J. J. Michal, and M. W. Cossalman. 2007. The $\mathrm{SF}_{6}$ Tracer Technique: Methane Measurement from Ruminants. Pages 33-67 in Measuring Methane Production From Ruminants. H. P. S. Makkar and P. E. Vercoe, ed. Springer, Amsterdam, the Netherlands.

Jonker, J. S., R. A. Kohn, and J. High. 2002. Dairy herd management practices that impact nitrogen utilization efficiency. J. Dairy Sci 85:1218-1226.

Külling, D. R., H. Menzi, T. F. Kröber, A. Neftel, F. Sutter, P. Lischer, and M. Kreuzer. 2001. Emissions of ammonia, nitrous oxide and methane from different types of dairy manure during storage as affected by dietary protein content. J. Agric. Sci. Camb. 137:235250.

Lapierre, H., and G. E. Lobley. 2001. Nitrogen recycling in the ruminant: A review. J. Dairy Sci. 84(E Suppl.):E223-E236.

Li, L., J. Cyriac, K. F. Knowlton, L. C. Marr, S. W. Gay, M. D. Hanigan, and J. A. Ogejo. 2009. Effects of reducing dietary nitrogen on ammonia emissions from manure on the floor of a naturally ventilated free stall dairy barn at low $\left(0\right.$ to $\left.20^{\circ} \mathrm{C}\right)$ temperatures. J. Environ. Qual. In press.

Li, L., J. A. Ogejo, L. C. Marr, K. F. Knowlton, M. D. Hanigan, and S. W. Gay. 2008. Ammonia emissions from dairy manure storage tanks. ASABE Meeting Presentation Paper Number: 084475. ASABE, St. Joseph, MI

McCleary, B. V., V. Solah, and T. S. Gibson. 1994. Quantitative measurement of total starch in cereal flours and products. J. Cereal Sci. 20:51-58.

McDougall, E. I. 1948. The composition and output of sheep's saliva. Biochem. J. 43:99-109. 
Milano, G. D., A. Hotston-Moore, and G. E. Lobley. 2000. Influence of hepatic ammonia removal on ureagenesis, amino acid utilization and energy metabolism in the ovine liver. Br. J. Nutr. 83:307315 .

Miller, K. A., D. S. Siscovick, L. Sheppard, K. Shepherd, J. H. Sullivan, G. L. Anderson, and J. D. Kaufman. 2007. Long-term exposure to air pollution and incidence of cardiovascular events in women. $\mathrm{N}$. Engl. J. Med. 356:447-458.

Misselbrook, T. H., J. M. Powell, G. A. Broderick, and J. H. Grabber. 2005. Dietary manipulation in dairy cattle: Laboratory experiments to assess the influence of ammonia emissions. J. Dairy Sci. 88:1765-1777.

Ndegwa, P. M., A. N. Hristov, J. Arogo, and R. E. Sheffield. 2008. A review of ammonia emissions mitigation techniques for concentrated animal feeding operations. Biosystems Eng. 100:453-469.

Ndegwa, P. M., V. K. Vaddella, A. N. Hristov, and H. S. Joo. 2009 Measuring concentrations of ammonia in ambient air or exhaust air stream using acid traps. J. Environ. Qual. 38:647-653.

Ni, J. Q., and A. J. Heber. 2008. Sampling and Measurement of Ammonia at Animal Facilities. Adv. Agron. 98:201-269.

NRC. 2001. Nutrient Requirements of Dairy Cattle. 7th rev. ed. National Academy Press, Washington, DC.

Oberdorster, G. 2000. Pulmonary effects of inhaled ultrafine particles. Int. Arch. Occup. Environ. Health 74:1-8.

Olmos Colmenero, J. J., and G. A. Broderick. 2006. Effect of dietary crude protein concentration on milk production and nitrogen utilization in lactating dairy cows. J. Dairy Sci. 89:1704-1712.

Powell, J. M., G. A. Broderick, and T. H. Misselbrook. 2008. Seasonal diet affects ammonia emissions from tie-stall dairy barns. J. Dairy Sci. 91:857-869.

Reynal, S. M., and G. A. Broderick. 2005. Effect of dietary level of rumen-degraded protein on production and nitrogen metabolism in lactating dairy cows. J. Dairy Sci. 88:4045-4064.

Reynolds, C. K., and N. B. Kristensen. 2008. Nitrogen recycling through the gut and the nitrogen economy of ruminants: An asynchronous symbiosis. J. Anim. Sci. 86(E. Suppl.):E293-E305.

Russell, J. B., C. J. Sniffen, and P. J. Van Soest. 1983. Effect of carbohydrate limitation on degradation and utilization of casein by mixed rumen bacteria. J. Dairy Sci. 66:763-775.

Russell, J. B., and R. J. Wallace. 1997. Energy-yielding and energyconsuming reactions. Pages 246-282 in The Rumen Microbial Ecosystem. P. N. Hobson, and C. S. Steward, ed. Blackie Academic and Professional, London, UK.

Schwab, C. G., P. Huhtanen, C. W. Hunt, and T. Hvelplund. 2005 Nitrogen requirements of cattle. Pages 13-70 in Nitrogen and Phosphorus Nutrition of Cattle and Environment. A. N. Hristov and E. Pfeffer, ed. CAB International, Wallingford, UK.

Shi, Y., D. B. Parker, N. A. Cole, B. W. Auvermann, and J. E. Mehlhorn. 2001. Surface amendments to minimize ammonia emissions from beef cattle feedlots. Trans. ASAE 44:677-682.
Soon, Y. K. 1998. Determination of cadmium, chromium, cobalt, lead, and nickel in plant tissues. Pages 193-198 in Handbook of Reference Methods for Plant Analysis, Y. P. Kalra, ed. CRC Press, Boca Raton, FL.

Thomsen, I. K. 2000. C and N transformations in 15N cross-labelled solid ruminant manure during anaerobic and aerobic storage. Bioresour. Technol. 72:267-274.

Udén, P., P. E. Colucci, and P. J. Van Soest. 1980. Investigation of chromium, cerium, and cobalt as markers in digesta. Rate of passage studies. J. Sci. Food Agric. 31:625-632.

USEPA (US Environmental Protection Agency). 2004. National Emission Inventory-Ammonia Emissions from Animal Husbandry Operations. US EPA, Washington, DC.

Valadares, R. F. D., G. A. Broderick, S. C. Valadares Filho, and M. K. Clayton. 1999. Effect of replacing alfalfa silage with high moisture corn on ruminal protein synthesis estimated from excretion of total purine derivatives. J. Dairy Sci. 82:2686-2696.

van Duinkerken, G., G. André, M. C. J. Smits, G. J. Monteny, and L. B. J. Šebek. 2005. Effect of rumen-degradable protein balance and forage type on bulk milk urea concentration and emission of ammonia from dairy cow houses. J. Dairy Sci. 88:1099-1112.

Van Keulen, J., and B. A. Young. 1977. Evaluation of acid-insoluble ash as a natural marker in ruminant digestibility studies. J. Anim. Sci. 44:282-287.

Van Soest, P. J., J. B. Robertson, and B. A. Lewis. 1991. Methods for dietary fiber, neutral detergent fiber, and nonstarch polysaccharides in relation to animal nutrition. J. Dairy Sci. 74:3583-3597.

Vander Pol, M., A. N. Hristov, S. Zaman, and N. Delano. 2007. Peas can replace soybean meal and corn grain in dairy cow diets. J. Dairy Sci. 91:698-703

Vander Pol, M., A. N. Hristov, S. Zaman, N. Delano, and C. Schneider. 2008. Effect of inclusion of peas in dairy cow diets on ruminal fermentation, digestibility, and nitrogen losses. Anim. Feed Sci. Technol. 150:95-105.

Verbic, J., X. B. Chen, N. A. Macleod, and E. R. Ørskov. 1990. Excretion of purine derivatives by ruminants: Effect of microbial nucleic acid infusion on purine derivative excretion by steers. J. Agric. Sci. 114:243-248.

Walker, N. D., C. J. Newbold, and R. J. Wallace. 2005. Nitrogen metabolism in the rumen. Pages 71-115 in Nitrogen and Phosphorus Nutrition of Cattle and Environment. A. N. Hristov and E. Pfeffer, ed. CAB International, Wallingford, UK.

Wattiaux, M. A., and K. L. Karg. 2004. Protein level for alfalfa and corn silage-based diets: I. Lactational response and milk urea nitrogen. J. Dairy Sci. 87:3480-3491.

Weiss, W. P., L. B. Willett, N. R. St-Pierre, D. C. Borger, T. R. McKelvey, and D. J. Wyatt. 2009. Varying forage type, metabolizable protein concentration, and carbohydrate source affects manure excretion, manure ammonia, and nitrogen metabolism of dairy cows. J. Dairy Sci. 92:5607-5619. 